\title{
Sharing Knowledge Agrifood Networks (SKAN) - a Portuguese project to promote technology links between Europe, Africa and Latin America
}

\author{
Sharing Knowledge Agrifood Networks (SKAN) - um projeto Português para a promoção de \\ ligações tecnológicas entre a Europa, África e América Latina
}

Luís Mira da Silva ${ }^{1}$, Duarte Bué Alves ${ }^{2}$

${ }^{1}$ School of Agriculture. University of Lisbon, Tapada da Ajuda 1349-017 Lisboa Portugal

${ }^{2}$ Ministry of Foreign Affairs, Largo Rilvas. Palácio das Necessidades, 1399-030 Lisboa Portugal

Email: luismira@inovisa.pt

\begin{abstract}
Three years ago, in 2013, the SKAN initiative - Sharing Knowledge Agrifood Networks (http://www.skanplatform. org/) was launched in Lisbon. The main objective was to create a "network of networks" to promote an international dialogue between all relevant actors at a political and diplomatic level, as well as the business community, universities and academia, with a focus on three continents: Europe, Africa and Latin America. More specifically, the initial aim was to promote the sharing of knowledge and technology at an international and comprehensive level in the agrifood sector.

In only three years the SKAN Platform achieved a prominent place in the development of networks of knowledge sharing in Portuguese speaking countries. The goal for the future is to increase the number of initiatives in the countries where SKAN is established and begin to collaborate and develop new initiatives in other countries. The project has produced significant outcomes and the return on the investment that was initially allocated has been high. We expect this initiative will have an impact on global challenges such as food security, agricultural development, or the transfer of technology, as well as the ability to strengthen the cooperation between Europe, Africa and Latin America in the agrifood sector.
\end{abstract}

Keywords: SKAN, Sharing Knowledge, Network, Agrifood, CPLP

\section{Resumo}

Há três anos atrás, em 2013, foi lançada em Lisboa a iniciativa SKAN - Sharing Knowledge Agrifood Networks (http://www.skanplatform.org/). O principal objetivo desta iniciativa era criar uma "rede de redes" que promovesse o diálogo internacional entre todos os atores relevantes ao nível político e diplomático, e ao nível da comunidade empresarial, universidades e meio académico, com um foco em três continentes: Europa, África e América Latina. Mais especificamente, o intuito era promover a partilha de conhecimento e tecnologia a um nível internacional e abrangente no setor agroalimentar.

Em três anos a Plataforma SKAN assumiu um lugar de destaque no desenvolvimento de redes de partilha de conhecimento nos países de língua Portuguesa. O objetivo para o futuro é aumentar o número de iniciativas nos países onde tem atuado e começar a desenvolver iniciativas noutros países. O projeto tem produzido resultados significativos e o retorno do investimento que inicialmente foi alocado tem sido elevado. Esperamos que esta iniciativa possa ter um impacto positivo em desafios globais tais como a segurança alimentar, o desenvolvimento da agricultura, ou a transferência de tecnologia, tendo a capacidade de fortalecer as ligações e a colaboração entre a Europa, a África e a América Latina no sector agroalimentar.

Palavras-chave: SKAN, Partilha de Conhecimentos; Rede; Agroalimentar; CPLP 


\section{The SKAN Platform}

Three years ago, in 2013, the SKAN initiative - Sharing Knowledge Agrifood Networks (www.skanplatform.org) was launched in Lisbon. The main aim of this initiative was to create a "network of networks" that would promote an international dialogue between relevant players at political and diplomatic level, the business community, universities and academia, with a main focus on three continents: Europe, Africa and Latin America. More specifically, the objective of the initiative was to promote knowledge and technology sharing, at a broad international level, in the agrifood sector.

The initial objective was very ambitious, and in fact it has shown during these three years to be a considerable challenge, difficult to put into practice, but at the same time with huge potential benefits to those at the "first mile" of the agrifood chain: the farmers, particularly the millions of small and medium size farmers that do not have access to the technology and knowledge they need to develop their operations and increase their returns. This need is not only of the farmers. Knowledge and technology are also needed at other levels of the value chain, including food processing, conservation or logistics.

As the initial objective was so ambitious, the focus of the SKAN platform has been directed, at a first stage, to the Portuguese Speaking Countries Community (CPLP). In the last three years, most of the work has been done in Portugal, Mozambique, Angola and Cape Verde, linking the SKAN partners in these countries with the large community of European academia and research institutions that work on agriculture and food research and innovation. Nevertheless, the initiatives that have been undertaken during this period have been very diverse, attracting people from many other countries, including Brazil, São Tomé e Principe, Guinea, Malawi, and South Africa.

The SKAN Platform is an answer to global challenges and emerging needs. The main challenge behind SKAN is the world population growth in the coming decades and the associated food security and nutrition problems, namely in developing countries, that has to be addressed in a sustainable and responsible manner. The needs are the efficiency of agrifood systems and the optimization of resource use, aimed at a green (and blue!) economic growth and social development. The SKAN Platform responds to these challenges and needs by promoting knowledge and technology sharing between Europe, Africa and Latin America in the agriculture and food sectors. SKAN aims to achieve this goal through an integrated approach that is focused on:

1)Strengthening the interplay between science and industry;

\section{A Plataforma SKAN}

Há três anos atrás, em 2013, foi lançada em Lisboa a iniciativa SKAN - Sharing Knowledge Agrifood Networks (http://www.skanplatform.org/). O principal objetivo desta iniciativa era criar uma "rede de redes" que promovesse o diálogo internacional entre todos os atores relevantes ao nível político e diplomático, e ao nível da comunidade empresarial, universidades e meio académico, com um foco principal em três continentes: Europa, África e América Latina. Mais especificamente, o objetivo inicial desta iniciativa era promover a partilha de conhecimento e tecnologia a um nível internacional e abrangente no setor agroalimentar.

O objetivo inicial era muito ambicioso e revelou-se, nos últimos três anos, como um grande desafio, difícil de por em prática mas, ao mesmo tempo, com grandes benefícios potenciais para aqueles que estão na "primeira linha" da cadeia agroalimentar: os agricultores. Em particular, os milhões de pequenos e médios agricultores que não têm acesso à tecnologia e conhecimento de que precisam para levar a cabo as suas atividades e aumentar o seu rendimento. Mas não é só aos agricultores que esta partilha faz falta. O conhecimento e a tecnologia são essenciais a outros níveis da cadeia de valor, incluindo a transformação alimentar, a conservação e a logística.

Sendo o objetivo inicial tão ambicioso, o foco da Rede SKAN tem estado direcionado, numa primeira instância, para os países da Comunidade de Países de Língua Portuguesa (CPLP). Nos últimos três anos, a maior parte do trabalho tem sido realizada em Portugal, Moçambique, Angola e Cabo verde, ligando os parceiros SKAN destes países à extensa comunidade de instituições académicas e de investigação europeias que trabalham em I\&D e inovação nos sectores agrícola e alimentar. Não obstante, as iniciativas levadas a cabo neste período tem sido muito diversas, atraindo pessoas de diferentes países, tais como o Brasil, São Tomé e Príncipe, Guiné-Bissau, Malawi e África do Sul.

A Rede SKAN surge como resposta a desafios globais e necessidades emergentes. O principal desafio por detrás do SKAN é o aumento da população esperado nas próximas décadas, e o problema de segurança alimentar e nutricional que daí advém. As necessidades são a eficiência dos sistemas agroalimentares e a otimização da utilização de recursos, tendo em vista o crescimento verde (e azul!) da economia e o desenvolvimento social. A Rede SKAN responde a estes desafios e necessidades através da promoção da partilha de conhecimento e tecnologia entre a Europa, a África e a América Latina, no sector agrícola e alimentar. O SKAN pretende atingir este objetivo através de uma abordagem integrada, que se foca em:

1) Reforçar a interação entre a ciência e as empresas; 
2)Integrating available resources, such as other networks and platforms, existing know-how, available scientific knowledge and funding sources for development and cooperation;

3) Enabling the development of international projects in consortium through a result oriented strategy;

4) Empowering local agents to ensure the sustainability of these projects.

Portugal has decided to launch this initiative for historical and political reasons. Portuguese universities and research institutions have for decades been developing a structured and comprehensive approach to tropical agriculture, merging local know-how with international in-depth research. In fact, Portugal has a long history of looking abroad to create critical mass in scientific and technological development. This may explain why Portuguese universities and research institutions have so many links with international institutions, particularly in Europe, Africa and Latin America, where it is possible to find numerous research projects and partnerships with Portuguese partners.

Existing scientific and technological skills and knowledge can only be useful when applied to respond to real challenges, such as food safety and nutrition, food security, sustainable resource management or climate change. On the other side, the vast majority of the research undertaken in the agriculture and food sectors should not belong to anyone in particular - and in fact it is not to be owned. It is, by its nature, to be shared, and to be at the service of the international community. That is at the core of the SKAN initiative.

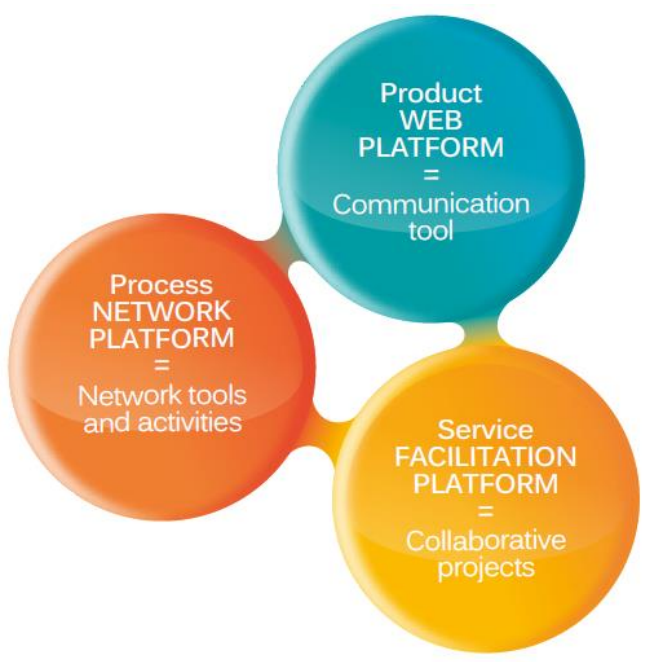

Figure 1 - The three SKAN Platform components
2) Integrar os recursos já existentes, tais como outras redes e plataformas, know-how, conhecimento científico disponível e fontes de financiamento para o desenvolvimento e cooperação;

3) Facilitar o desenvolvimento de projetos internacionais em consórcio, através de uma estratégia orientada para os resultados;

4) Capacitar agentes locais para assegurar a sustentabilidade destes projetos.

Portugal decidiu lançar esta iniciativa por razões políticas e históricas. As universidades e centros de investigação portugueses têm vindo a desenvolver nas últimas décadas uma abordagem estruturada e agregadora à agricultura tropical, fundindo know-how local com investigação internacional. De facto, Portugal tem um longo historial de olhar para fora, de forma a criar massa crítica no desenvolvimento científico e tecnológico. Isto poderá explicar o porquê das universidades e centros de investigação portugueses terem tantas ligações com instituições internacionais, em particular na Europa, em África e na América Latina, onde se encontram um grande número de projetos de investigação e parcerias com parceiros portugueses.

O conhecimento e as técnicas científicas e tecnológicas só podem ser úteis quando usadas para lidar com desafios reais, como a segurança alimentar e nutricional, a gestão sustentável dos recursos ou as mudanças climáticas. Por outro lado, a grande maioria da investigação levada a cabo nos sectores agrícola e alimentar não pertence a ninguém - e, de facto, não deve pertencer: é, por natureza, para ser partilhada e para estar ao serviço da comunidade internacional. Este é o cerne da iniciativa SKAN.

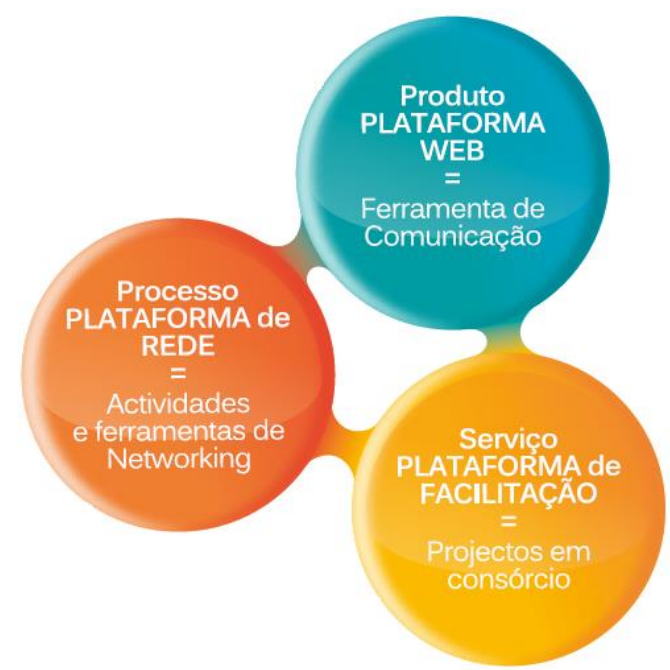

Figura 1 - As três componentes da iniciativa SKAN 
The SKAN Platform works within three main components (Figure 1). First, it works as an integrated Web and networking platform, where people can virtually meet and share information, as in a social digital network. In this context, it focuses mainly on communication, bringing stakeholders together as a channel for sharing digital contents and information about agriculture and food. Second, it works as a tool to promote presentational meetings, organising networking events, workshops, or brokerage events, bringing together a diversity of actors that contribute to the development of the agrifood sector, including farmers, business leaders, and researchers.

The third component of SKAN is a facilitation platform, a structure to promote the development of projects in consortium between international institutions from the research, business or public sectors, enhancing the potential of knowledge sharing and technology transfer. In this facilitation platform the SKAN team can help to select partners, identify sources of financing, and help to structure the applications of the projects. It is therefore a natural extension of the Web and the networking platforms, increasing the potential of the SKAN initiative. The SKAN initiative is a long term project that is just beginning, but many positive outcomes can already be claimed. Formal partnerships have been developed with many institutions and in several countries, including Mozambique, Angola, Cape Verde and Brazil. Two large scale projects in Africa were launched with the collaboration of the SKAN team, and several applications to European projects have been supported in the last year. Since the beginning of 2016, the SKAN team has two people working in Africa - one in Mozambique, based at the local FAO offices, and another in Cape Verde, based at the Ministry of Agriculture and Environment. This has created new opportunities for partnerships and projects in collaboration with institutions in these two countries.

A great part of the work that has been done was to support networking and develop or strengthen collaborations. Leadership workshops for higher education and research institutions in the agrifood sector have been organized in several countries in Africa, namely Mozambique, Cape Verde and Malawi. Several workshops, seminars and technology brokerage events have been and are currently being organized in several countries in Africa and Latin America. An international workshop was recently organised in Lisbon together with Agrinatura, an association of the major research and education stakeholders in Europe dealing with agricultural research and higher education for development. Several projects are also being prepared or have been applied together with Ruforum, the Regional Universities Fo-
A plataforma SKAN integra três componentes principais (Figura 1). A primeira diz respeito a uma plataforma Web de networking, onde os utilizadores podem conhecer-se virtualmente e partilhar informações, como numa rede social digital. Neste contexto, a rede concentra-se principalmente na comunicação, juntando stakeholders num canal de partilha de conteúdos digitais sobre agricultura e alimentação. Em segundo lugar, funciona como uma ferramenta para promover encontros presenciais, organizar eventos de networking, workshops ou eventos de brokerage, juntando diversos atores que contribuem para o desenvolvimento do sector agroalimentar, incluindo agricultores, empresários e investigadores.

A terceira componente do SKAN é uma plataforma de facilitação, uma estrutura para promover o desenvolvimento de projetos em consórcio entre instituições internacionais dos sectores da investigação, empresarial ou público, promovendo o potencial da partilha de conhecimento e transferência de tecnologia. Nesta plataforma de facilitação, a equipa SKAN pode ajudar na seleção de parceiros, na identificação de fontes de financiamento e na elaboração das candidaturas de projetos. Esta componente é, assim, uma extensão natural das plataformas web e de rede, aumentando o potencial da iniciativa SKAN.

A iniciativa SKAN é um projeto a longo-prazo que ainda está no seu início, mas que já demonstrou muitos resultados positivos. Foram desenvolvidas parcerias formais com muitas instituições e em diversos países, incluindo Moçambique, Cabo Verde e Brasil. Foram lançados dois projetos de grande escala em África com a colaboração da equipa SKAN e foram apoiadas diversas candidaturas a projetos europeus no último ano. Desde o início de 2016 que a equipa SKAN tem duas pessoas a trabalhar em África - uma em Moçambique, localizada nos escritórios da FAO, e outra em Cabo Verde, sediada no Ministério da Agricultura e Ambiente. Isto criou novas oportunidades para parcerias e projetos em colaboração com instituições destes dois países.

Uma grande parte do trabalho desenvolvido serviu para apoiar o networking e desenvolver ou fortalecer colaborações. Foram organizados workshops de liderança para instituições de ensino superior e de investigação do sector agroalimentar em vários países africanos, nomeadamente em Moçambique, Cabo Verde e Malawi. E foram, e estão a ser atualmente, organizados diversos workshops, seminários e eventos de brokerage de tecnologias em vários países de África e da América Latina. Recentemente, foi organizado em Lisboa um workshop internacional em conjunto com a Agrinatura, uma associação dos maiores stakholders da investigação e educação da Europa que trabalham em investiga- 
rum for Capacity Building in Agriculture, a consortium of more than 30 universities from Eastern, Central and Southern Africa.

An initiative such as this usually takes time to take off and sometimes struggles to find its place amid the multiple networks and international partnerships that are created every year. This has not been the case with the SKAN platform. In fact, in only three years the platform has created a "brand" and a credibility status in some countries, which provides excellent prospects for the next few years. The objective for the future is to increase the number of initiatives and projects in the countries where we have been, and start to collaborate and develop new initiatives in countries where we have not yet had the chance to go. The externalities of the project are huge, and the return on the investment that was initially put in the SKAN platform is high. What is still lacking is to increase the mobility and interchange programs among the SKAN partner institutions, and bring people from African or Latin America partners to work with short term assignments in Portugal. This would further strengthen the relationships between partners.

We expect that this initiative can have a positive impact in global challenges such as food security, agriculture development, climate change or technology and knowledge transfer, having the capacity to strengthen the links and the collaboration between Europe, Africa and Latin America. In only three years it was possible to achieve results that were well beyond expectations at the time the platform was launched. In the next few years, if we manage to keep the current track record, we would like to claim that we have managed to contribute to the development of the agrifood sector at the global level.

\section{Conflict of interests}

The authors declare that there are no financial and/or personal relationships that could be viewed as presenting a potential conflict of interests. ção agrícola e ensino superior para o desenvolvimento. E estão a ser preparados, ou já se candidataram, vários projetos em conjunto com o Ruforum - Fórum Regional de Universidades para o Desenvolvimento de Competências na Agricultura, um consórcio de mais de 30 universidades da África Oriental, Central e Austral.

Uma iniciativa como esta normalmente demora algum tempo a arrancar, e por vezes tem dificuldade em encontrar o seu lugar no meio das múltiplas redes e parcerias internacionais criadas todos os anos. Este não foi o caso da plataforma SKAN. De facto, em apenas três anos a plataforma criou uma "marca" e um estatuto de credibilidade em alguns países, o que fornece excelentes perspetivas para os próximos anos. O objetivo para o futuro é aumentar o número de iniciativas e projetos nos países onde temos atuado e começar a colaborar e desenvolver novas iniciativas em países onde ainda não tivemos a hipótese de estar presentes. As externalidades do projeto são enormes e o retorno do investimento que inicialmente foi alocado à plataforma SKAN é elevado. O que ainda falta é aumentar a mobilidade e o intercâmbio entre as instituições parceiras do SKAN e trazer pessoas dos parceiros Africanos e da América Latina para Portugal através de programas de curto prazo. Isto fortaleceria ainda mais as relações entre os parceiros.

Esperamos que esta iniciativa possa ter um impacto positivo em desafios globais tais como a segurança alimentar, o desenvolvimento da agricultura, as alterações climáticas ou a transferência de tecnologia e conhecimento, tendo a capacidade de fortalecer as ligações e a colaboração entre a Europa, a África e a América Latina no sector agroalimentar. Em apenas três anos foi possível alcançar resultados muito superiores aos esperados aquando do lançamento da plataforma. Nos próximos anos, se conseguirmos manter o registo atual, gostaríamos de poder afirmar que contribuímos para o desenvolvimento do sector agroalimentar ao nível global.

\section{Conflito de interesses}

Os autores declaram não existir qualquer relação pessoal ou financeira que possa ser entendida como representando um potencial conflito de interesses. 